\title{
PEMANFAATAN MEDIA PEMBELAJARAN E-LEARNING MENGGUNAKAN WHASTSAPP SEBAGAI SOLUSI DITENGAH PENYEBARAN COVID-19 DI MI NURULHUDA JELU
}

\author{
Imam Ja'far Shodiq ${ }^{1)}$, Husniyatus Salamah Zainiyati ${ }^{2)}$ \\ ${ }^{1,2)}$ Pascasarjana Magister Pendidikan Agama Islam UIN Sunan Ampel \\ Surabaya \\ E-mail: $\underline{\text { imamjs1989@gmail.com }}{ }^{1)}, \underline{\text { husniyatussalamah@uinsby.ac.id }{ }^{2}}$
}

\begin{abstract}
ABSTRAK
Di era modern seperti saat ini teknologi informasi telah mengalami perkembangan yang sangat pesat, khususnya dalam ilmu pendidikan penggunaan internet dalam pendidikan terus berkembang. E-leraning merupakan bentuk pembelajaran yang memanfaatkan perangkat- elektronik baik yang menggunakan akses internet maupun tidak. Dalam dunia pendidikan sendiri penggunaan akses internet sudah banyak digunakan untuk pemanfaatan aplikasi/sytem sebagai media pembelajaran. Dunia pendidikan saat ini tengahh dihebohkan dengan munculnya penyebaran wabah virus covid-19, yang secara tidak langsung sudah berimbas pada dunia pendidikan. Salah satu imbas yang kita rasakan saat ini adalah adanya pemberlakuan belajar secara daring bagi siswa, dari semua tingkatan di seluruh Indonesia. Sebagai pendidik tentu harus bisa beradaptasi secara tepat agar proses pembelajaran tetap bisa berjalan dengan maksimal, meskipun pembelajaran dilaksanakan dengan system daring, tentu salah satu hal yang harus dipersiapkan oleh seorang pendidik, dalam rangka penerapan pembelajaran daring adalah efektifitas dan ketepatan dalam pemilihan media pembelajaran dengan menyesuaikan keadaan peserta didik. Salah satu media yang bisa digunakan adalah Whattshap, karena Whattshap memiliki banyak fitur seperti untuk kirim pesan, kirim gambar, video, suara, buat grup dan lain-lain serta mudah dalam pengoperasiannya. Dalam tulisan ini akan kita coba untuk menguraiakan seberapa manfaat WA dalam mendukung pembelajaran jarak jauh siswa, kendala-kendala yang dihadapi dan bagaimana keuntungan/keunggulannya.
\end{abstract}

Kata kunci: E-learning, Pembelajaran, Whatsapp, Covid 19

A. PENDAHULUAN 
Di era saat ini teknologi komunikasi telah mengalami perkembangan yang begitu pesat, internet merupakan salah satu teknologi yang saat ini sangat pesat perkembangannnya. Internet seakanakan sudah menjadi kebutuhan pokok manusia dari kalangan atas sampai bawah, dari kalangan tua sampai anak-anak, bahkan internet juga sudah mendunia sehingga dunia ini terasa tanpa ada batas. Informasi dan komunikasi dalam waktu sekejap dapat kita peroleh, meskipun dari belahan dunia yang sangat jauh dari tempat kita berada. ${ }^{1}$

Di Indonesia sendiri, perkembangan teknologi dan informasi juga telah mengalami kemajuan yang sangat pesat, khususnya dalam dunia pendidikan banyak sekali saat ini kita jumpai metode pembelajaran yang diterapkan dengan memanfaatkan akses internet.

Keberadaan internet itu sendiri sebagai salah satu alat untuk memperoleh informasi, belum mampu menggantikan peran utama buku teks sebagai sumber informasi bagi para siswa/mahasiswa untuk menyelesaikan tugas-tugas yang mereka kerjakan. Akan tetapi empat domain dalam proses belajar Taksonomi Bloom, dapat dicapi dengan pencarian informasi menggunakan fasilitas internet. ${ }^{2}$

Seiring dengan kemajuan teknologi dan informasi yang sangat pesat, perkembangan media pembelajaran juga mengalami perkembangan yang sangat signifikan, hal tersebut dapat dilihat dari semakin banyaknya metode atau media pembelajaran dengan memanfaatkan akses internet. Teknologi saat ini juga sudah mampu menggantikan teknologi yang ada pada beberapa tahun yang lalu, termasuk juga menggantikan metode pembelajaran secara konvensional. Banyak sekali teknologi yang dapat kita manfaatkan untuk pebelajaran saat ini, salah satunya adalah dengan memanfaatkan e-learning. Dengan munculnya e-learning sebagai salah satu bentuk inovasi dalam pembelajaran, peserta didik tidak hanya mampu memperoleh uraian materi tetapi juga berbagai potensi peserta didik juga mengalami perubahan. Dengan e-learning peseta didik juga akan aktif dalam

${ }^{1}$ Sri Rahayu Chandrawati;Pemanfaatan E-Learning dalam pembelajaran;Jurnal Cakrawala KependidikanVol.8 No.2 September 2010

2 Husniyatus Salamah Zainiati, "Understanding the Cognition Process of the Students Using the Internet as a Learning Resource," Jurnal Pendidikan Islam 3, no. 1 (2017): 57. 
mengamati, mendemonstrasikan, melakukan, dan lain sebagaianya. Disamping itu materi bahan ajar juga dapat di virtualisasikan dengan semenarik mungkin dengan berbagai bentuk sesuai dengan yang kita kehendaki, sehingga membuat peserta didik untuk lebih nyaman dan betah/tidak mudah jenuh dalam prses pembelajaran. ${ }^{3}$ Disamping itu $e$ learning juga sangat cocok utuk diterapkan dalam pembelajaran daring tanpa harus ada pertemuan tatap muka langsung antara pendidik dan peserta didik.

Baru-baru ini pemerintah melalui kemendikbud mengeluarkan kebijakan berupa intruksi pembelajaran dilakukan dirumah untuk seluruh sekolah/madrasah seiring adanya penyebaran covid-19, termasuk kebijakan bagi seluruh tenaga pendidik atau kependidikan untuk melakukana pekerjaannnya di rumah masing-masing, atau kita dikenal dengan istilah Work From Home (WFH). Hal ini dilakukan dalam rangka untuk memutus mata rantai penularan covid-19. ${ }^{4}$

Dengan adanya kebijkan ini, tentu sudah tidak ada lagi pembelajaran luring atau tatap muka antara guru dengan siswa, sebagaimana yang biasanya dilakukan oleh guru dan siswa didalam kelas, sekarang harus dilakukan dengan jarak jauh menggunakan system daring/online.

Dalam kondisi seperti saat ini, agar pembelajaran siswa tetap bisa berlangsung dengan maksimal, pendidik dituntut untuk berupaya memaksimalkan pembelajaran jarak jauh menggunakan system online/daring, dengan menggunakan e-learning sebagai salah satu media pembelajaran dengan memanfaatkan akses internet, disamping itu pendidik juga dipaksa untuk merubah model/strategi pembelajaran yang biasanya diterapakan secara klasikan mejadi digital.

Dalam penggunaan E-learning pendidik harus betul-betul mempertimbangkan beberapa hal misalnya: kemampuan siswa dalam teknologi, kondisi/latarbelakang orang tua, dan sarana prasarana yang ada, hal tersebut perlu dilakukan agar nanti ketika sudah menggunakan perangkat yang dipilih tidak menimbulkan masalah baru.

\footnotetext{
${ }^{3}$ Wiwin Hartanto, "Penggunaan E-Learning Sebagai Media Pembelajaran," Jurnal Pendidikan Ekonomi 10, no. 1 (2016): 1-18.

4 https://www.kompas.com/tren/read/2020/03/16/195035165/jokowi-instruksikanbekerja-dari-rumah-ini-arti-work-from-home?page=all
} 
Salah satu bentuk E-leraning yang mudah dimanfaatkan lebihlebih bagi siswa tingkat bawah yang berada dipedesaan adalah menggunakan e-learning (berbasis) whastshapp, mengingat hampir semua orang pedesaan memiliki aplikasi ini, dan aplikasi ini sangat mudah untuk dioperasikan serta sangat efektif. Sebagaimana hasil sebuah penelitian yang dilakukan oleh Trisnani dengan judul: Pemanfaatan Whatsapp sebagai media komunikasi dan kepuasan dalam penyampaian pesan dikalangan tokoh masyarakat diperoleh kesimpulan bahawa: tokoh masyarakat lebih suka menggunakan WA sebagai media komunikasi untuk menyampaikan pesan ke masyarakat karena lebih efektif dan tepat sasaran. ${ }^{5}$

Disamping itu komunikasi yang terjalin dengan menggunakan whatsapp menjadi lebih lancar, dan lebih mudah untuk mengenali teman dekatnya. ${ }^{6}$ Dengan memanfaatkan aplikasi whatsapp ini guru bisa berinteraksi dan berkomunikasi untuk memberikan informasi dan melakukan proses pembelajaran dengan efektin dan tepat sasaran.

Dari uraian diatas, penelitian ini bertujuan untuk mendapatkan gambaran seberapa jauh pemanfaatan whatsaapp sebagai media pembelajaran siswa sebagai solusi ditengah menyebarnya wabah covid19.

\section{B. PEMBAHASAN}

\section{Pengertaian E-Learning}

Secara bahasa e-learning berasal dari kata ' $e$ ' yang berarti electronic dan 'learning' yang berarti pembelajaran. Sehingga kata $e$ learning bisa di artikan pembelajaran yang memanfaatkan jasa elektronika. Sedangkan pengertian e-learning secara umum adalah materi pembelajaran yang dikirim menggunakan suata alat media elektronik bisa berupa intranet/extranet, internet, audio/video, tape, satellite broadcast, interactive TV, CD-ROM, dan computer-based

5 - Trisnani, "Pemanfaatan Whatsapp Sebagai Media Komunikasi Dan Kepuasan Dalam Penyampaian Pesan Dikalangan Tokoh Masyarakat," Jurnal Komunika: Jurnal Komunikasi, Media dan Informatika 6, no. 3 (2017).

${ }^{6}$ Mei Yusmita, Zulfiah Larisu, and Saidin, "Pemanfaatan WhatsApp Messenger Sebagai Media Komunikasi Antar Pribadi Mahasiswa Ilmu Komunikasi *Mei Yusmita ** Dr. Zulfiah Larisu, S.Sos, M.Si., *** Saidin, S.Ip, M.Si.” (2014): 1-12. 
training (CBT), sehingga lebih fleksibel untuk mendukung dan meningkatkan proses pengajaran, pembelajaran dan penilaian. Sedangkan lebih khusus e-learning juga dapat diartikan sebagai suatu pemanfaatan teknologi internet untuk menyebarkan/mentransfer materi pembelajaran, sehingga dapat diakses oleh peserta didik kapanpun dan dimanapun mereka berada. ${ }^{7}$

E-Learning merupakan suatu pembelajaran yang mana proses transformasi pembelajaran atara peserta didik dengan pendidik menggunakan teknologi informasi dan komunikasi. ${ }^{8}$ E-learning ialah suatu teknologi informasi dan komunikasi yang bisa menjadikan peserta didik lebih aktif dalam belajar dimanapun dan kapanpun mereka membutuhka. ${ }^{9}$ E-learning adalah penggabungan antara prinsip-prinsip pembelajaran dengan teknologi informasi dalam suatu pembelajaran yang dilakukan dengan cara jarak jauh. ${ }^{10}$

Jaya Kumar C. Koran mengatakan bahwa e-learning merupakan suatu proses pengajaran dan pembelajaran yang cara menyampaikan isi pembelajaran, interaksi, atau bimbingan dengan memanfaatkan alat elektronik baik berupa internet, LAN atau WAN). Disamping itu ada pula yang mengartikan bahwa e-learning adalah bentuk pembelajaran jarak jauh dengan memanfaatkan fasilitas jaringan internet sebagai penghubungnya. $^{11}$

Secara umum ada beberapa manfaat dari e-leraning bagi dunia pendidikan antara lain:

1. Perubahan budaya belajar dan peningkatan mutu kegiatan belajar mengajar;

2. Meningkatkan Brand Image;

3. Tersedianya materi pembelajaran yang luas, yang mudah diakses $;{ }^{12}$

${ }^{7}$ Suryati;Sistem Manajemen Pembelajaran Online, Melalui E-Learning.

8 Hernik Pujiastutik;Efektivitas Penggunaan Media Pembelajaran Elearning Berbasis Web Pada Mata Kuliah Belajar Pembelajaran I Terhadap Hasil Belajar Mahasiswa; Jurnal Teladan, Volume 4 No. 1, Mei 2019

${ }^{9}$ Hartanto, "Penggunaan E-Learning Sebagai Media Pembelajaran."

${ }^{10}$ Sri Rahayu Chandrawati;Pemanfaatan E-Learning dalam pembelajaran;Jurnal Cakrawala KependidikanVol.8 No.2 September 2010

${ }^{11}$ Mohammad Yazdi ;E-Learning Sebagai Media Pembelajaran Interaktif Berbasis Teknologi Informasi; Jurnal Ilmiah Foristek Vol. 2, No. 1, Maret 2012

12 Sri Rahayau Candrawati, "Pemanfaatan E-Learning Dalam Pembelajaran," Jurnal Cakrawala Kependidikan Cakrawala Kependidikan (n.d.): 172-181. 
4. Independent learning

5. Efektifitas pengajaran

6. Fleksibilitas tempat dan waktu;

7. Kecepatan distribusi

8. Penghematan biaya;

9. Ketersediaan On-Demand;

10. Standarisasi pengajaran;

11. Fleksibilitas kecepatan pembelajaran. ${ }^{13}$

\section{Fungsi E-Learaning}

Adapun fungsi e-learning pada suatu pembelajaran dibagi menjadi 3 antara lain:

1. Tambahan (Suplemen)

Peserta didik memiliki kebebasan untuk memilih, apakah belajara dengan tradisonal atau menggunakan e-leraningg, karena tidak ada kewajiban bagi mereka untuk menggunakan e-leraning, jadi hanya bersifat opsional. Meskipun demikian siswa yang menggunakan $e$-learning, jauh akan lebih memiliki wawasan dan pengetahun yang luas.

2. Pelengkap (Komplemen)

Fungsi ini diprogramkan untuk menjadi materi reinforcement (pengayaan) atau memberikan remedi untuk peserta didik didalam mengikuti pembelajaran tradisional.

3. Pengganti (Substitusi)

Bagi sekolah yang sudah maju biasanya menyediakan alternative pembelajaran berupa e-learning, hal ini dimaksudkan agar jika sewaktu-waktu jika pendidik tidak bias hadir dalam kelas bisa dengan mudah menggnatinya dengan melakukan pembelajaran menggunakan e-learning, disamping itu juga siswa secara fleksibel dapat mengelola kegiatan pembelajarannya sesuai aktifitas sehari-hari. ${ }^{14}$

\section{Kelebihan dan kekurangan E-Learning}

Segala sesuatu pasti memiliki kelebihan dan kekurangan, termasuk juga sebuah metode pembelajaran sudah pasti memiliki kelebihan dan

\footnotetext{
${ }^{13}$ Hartanto, "Penggunaan E-Learning Sebagai Media Pembelajaran."

${ }^{14}$ Sri Rahayau Candrawati, "Pemanfaatan E-Learning Dalam Pembelajaran."
} 
kekurangan. E-learning sebagai salah satu metode pembelajaran memiliki bebrapa kelebihan antara lain:

1. Kwalitas pembelajar menjadi lebih optimal;

2. User friendly, bebas dari kerepotan dan

3. Cara belajar yang aman, nyaman dan sehat;

4. Waktu proses belajar mengajar menjadi lebih hemat;

5. Ilmu dan pengetahuan peserta didik dapat berkembang, serta peserta didik lebih bisa mandiri;

6. Tidak menggunakan kertas;

7. Peserta didik dapat mengakses sesuai dengan keinginannya, sehingga lebih fleksibel.15

8. Tersedianya fasilitas e-moderating;

9. Siswa dan guru bisa memanfaatkan bahan ajar yang telah tersedia melalui akses internet

10. Siswa bisa dengan mudah untuk mempelajari kembali bahan ajar kapanpun sesuai dengan yang dikehendaki, karena bahan ajar sudah ada didalam computer.

11. Dengan memanfaatkan akses internet, siswa dengan leluasa bisa memperoleh informasi materi pembelajaran yang terkait sesuai dengan yang dibutuhkan.

12. Dapat digunakan sebagai ajang diskusi bagi pendidik dan peserta didik, tanpa ada batasan jumlah, sehingga bisa menambah wawasan keilmuan yang lebih luas.

13. Peserta didik yang awalnya pasif akan berubah menjadi lebih aktif.

14. Biaya transportasi menjadi lebih hemat.

15. Secara keseluruhan biaya pendidikan menjadi lebih hemat.

16. Wilayah yang dijangkau jauh lebih luas. ${ }^{16}$

Disamping kelebihan-kelebihan diatas, e-learning juga tak lepas dari kekurangan, adapun kekurangannya antara lain:

1. Proses interaksi langsung antara guru dan siswa jauh menjadi berkurang, bahkan interaksi langsung antar siswapun juga akan jarang dilakukan mengingat mereka sudah berkomunikasi

${ }^{15}$ Marzuqi Agung Prasetya, "E-Learning Sebagai Sebuah Inovasi Metode Active Learning," Edukasia : Jurnal Penelitian Pendidikan Islam 10, no. 2 (2015): 319-338.

${ }^{16}$ Ade Kusuma, "E-Learning Dalam Pembelajaran," Lentera Pendidikan 14 (2011): $35-51$. 
menggunakan e-learning. Sehingga hal ini dapat menghambat terbentuknya value-value dalam kegiatan belajar-mengajar.

2. Kecenderungan mendorong tumbuhnya aspek bisnis serta terabaikannya aspek akademik atau aspek sosial.

3. Berubahnya peran pendidik dari yang semula menguasai teknik pembelajaran konvensional.

4. Lebih cenderung kearah pelatihan daripada kearah pendidikan.

5. Belum meratanya akses internet disetiap daerah, yang disebabkan oleh belum tersedianya aliran listrik, telepon, ataupun internet).

6. Siswa yang motivasi belajarnya rendah, akan cenderung gagal.

7. Rendahnya skill peserta didik dalah menggunakan teknologi. ${ }^{17}$

\section{Pengertian Whatsapp}

Perubahan zaman saat ini terasa begitu pesat, hal ini ditandai dengan semakin berkembangnya dunia teknologi informasi dan komunkasi. Perubahan ini menjadikan kehidupan social masyarakat juga ikut berubah. Saat ini setiap orang dapat mengakses informasi dengan mudah dan cepat meskipun berada pada tempat yang jauh, setiap orang juga bisa berkomunikasi jarak jauh dengan memanfaatkan media sosisal, salah satuanya adalah menggunakan Whatsapp. Tentu hal ini berbanding jauh dengan masa lampau.

Whatsapp merupakan sebuah aplikasi yang berbasis pesan untuk smartphone, dengan basic mirip Blackberry Messenger. ${ }^{18}$ Whatsapp massanger adalah aplikasi pesan lintas platform yang memudahkan kita untuk mengirim pesan tanpa adanya biaya sms, hal tersebut disebabkan karena aplikasi Whatsapp Massanger menggunakan akses data internet dalam pengoperasiannya. ${ }^{19}$

\section{Fungsi dan Manfat Whatsapp}

${ }^{17}$ Ibid.

18 Eka Indaryani, dan Dwi Suliworo ;Dampak pemanfaatan WhatsApp dalam meningkatkan motivasi belajar siswa pada pelajaran fisika; Prosiding Seminar Nasional Quantum;2018

${ }^{19}$ Rani Suryani, Fungsi Whatsapp Grup Shalehah Cabang Bandar Lampung sebagai Pengembangan Media Dakwah dalam Membentuk Akhlakul Kharimah, (Lampung :2017), hal. 18 
Whatsapp ialah apliksai berbasis pesan yang memudahkan kita untuk bertukar pesan tanpa dikenai biaya sms, karena Whatshapp memanfaatkan akses internet. Sehingga dengan whatshapp kita dapat mengirimkan file dokumen, file foto, video call, lokasi GPS dan lainlain.

Aplikasi whatsaap juga memiliki fasilitas Broadcast dan Group sehingga memudahkan guru untuk mengkondidikan siswa 1 kelas dalam satu grup. Whatsapp juga memiliki status pesan yang berupa tanda yang berfugsi untuk mengetahui status pesan tersebut, sehingga guru dapat memantau siswa apakah sudah membuka, membaca atau belum sama sekali. $^{20}$

Didalam pembelajaran ada beberapa manfaat aplikasi Whatsapp Messenger Group antara lain :

1. Whatsapp Messenger Group adalah aplikasi yang bisa diperoleh secara mudah dan gratis;

2. Whatsapp Messenger Group memiliki beberapa fasilitas antara lain untuk mengirim komentar, tulisan, gambar, video, suara, dan dokumen;

3. Whatsapp Messenger Group dapat digunakan untuk mempublikasikan karya atau menyebarkan informasi dengan cepat dan mudah;

4. Whatsapp Messenger Group memiliki berbagai fitur sehingga dapat dengan mudah dibuat untuk menyebarluaskan informasi dan pengetahuan;

5. Whatsapp Messenger Group memberikan kemudahan dalam pembelajaran secara online antara pendidik dan peserta didik ataupun sesama peserta didik, dimanapun mereka berada. ${ }^{21}$

\section{Covid-19}

Coronavirus adalah keluarga besar virus yang menyebabkan penyakit mulai dari gejala ringan sampai berat. Ada setidaknya dua jenis

${ }^{20}$ Rani Suryani, "Fungsi Whatsapp Grup Shalihah Cabang Bandar Lampung Sebagai Pengembangan Media Dakwah Dalam Membentuk Akhlakul Karimah" (2017).

${ }^{21}$ Eka Indaryani and Dwi Suliworo, "Dampak Pemanfaatan WhatsApp Dalam Meningkatkan Motivasi Belajar Siswa Pada Pelajaran Fisika," Prosiding Seminar Nasional Quantum 25 (2018): 25-31. 
coronavirus yang diketahui menyebabkan penyakit yang dapat menimbulkan gejala berat seperti Middle East Respiratory Syndrome (MERS) dan Severe Acute Respiratory Syndrome (SARS). Coronavirus Diseases 2019 (COVID-19) adalah penyakit jenis baru yang belum pernah diidentifikasi sebelumnya pada manusia. Tanda dan gelaja umum infeksi COVID-19 antara lain gejala gangguan pernapasan akut seperti demam, batuk, dan sesak napas. Masa inkubasi rata-rata 56 hari dengan masa inkubasi terpanjang 14 hari. $^{22}$

Coronavirus adalah virus RNA strain tunggal positif, berkapsul dan tidak brsegmen. Virus ini termasuk golongan ordo Nidovirales, keluarga Coronaviridae. Struktur coronavirus membentuk struktur seperti kubus dengan protein $\mathrm{S}$ berlokasi di permukaan virus. Protein $\mathrm{S}$ ini memiliki peran dalam penempelan dan masuknya virus kedalam sel host. $^{23}$

\section{PEMANFAATAN E-LEARNING BERBASIS WHATSAPP DALAM PEMBELAJARAN}

Dimasa pandemi seperti ini penerapan pembelajaran daring (jarak jauh) tentunya membutuhkan media yang efektif dan tepat sesuai kondisi atau kemampuan peserta didik. Whatsapp merupakan salah satu alternative pilihan media pembelajaran yang sangat tepat, bila dibandingkan dengan media pembelajaran online lainnya, hal tersebut dikarenakan whatsapp adalah aplikasi yang sangat sederhana, mudah dalam pengoperasiannya, whatsapp memiliki fitur-fitur/fasilitas yang lumayan lengkap, antara lain: 1) Pembuatan Grup chatting: fitur ini tentu bisa dimanfaatkan pendidik dan peserta didik untuk melakukan kegiatan pebelajaran secara terbatas, yang hanya bias diikuti oleh peserta didik yang ada dalam satu kelas tersebut. Bahkan dalam fitur ini pendidik bisa mengatur dalam grup hanya admin yang dapat mengirim pesan jika hal ini diperlukan, agar pembelajaran bisa kondusif. Dan pendidik pendidik

${ }^{22}$ Wahyu Aji et al., "Dampak Covid-19 Terhadap Implementasi Pembelajaran Daring Di Sekolah Dasar," Edukatif: Jurnal Ilmu Pendidikan 2, no. 1 (2020): 55-61, https://edukatif.org/index.php/edukatif/article/view/90.

23 Yuliana, "Corona Virus Diseases (Covid -19); Sebuah Tinjauan Literatur," Wellness and healthy magazine 2, no. 1 (2020): 187-192, https://wellness.journalpress.id/wellness/article/view/v1i218wh. 
juga bisa mengubah pengaturan menjadi semua peserta grup bisa mengirim pesan agar semua ikut berpartisipasi dalam memberikan tanggapan pada materi yang disampaikan. 2) Video Call : Fitur ini bisa dimanfaatkan oleh pendidik dan peserta didik untuk mengkroscek secara langsung, apakah peserta didik betul-betul mengikuti pembelajaran atau hanya sekedar mengaktifkan aplikasinya saja. Atau bisa juga dimanfaatkan untuk melakukan ujian lisan secara langsung. 3) Kirim pesan : Dalam Whatshapp pengiriman pesan bisa berupa file, gambar, Audio, Video, dan lokasi), tentu fitur-fitur ini sangat membantu pendidik, hal tersebut disebabkan karena dengan adanya fitur ini pendidik bisa secara leluasa menyampaikan materi dengan merekam misalnya, kemudian di dukung dengan gambar-gambar dan video agar peserta didik mampu memahami secara baik materi yang disampaikan oleh pendidik. 4) Whatsapp juga memiliki fitur untuk mengetahui seseorang dalam menerima informasi, biasanya secara umum dibedakan menjadi tiga yakni centang satu artinya pesan terkirim namun whatshapp tersebut tidak aktif, centang dua warna abu-abu pesan terkirim, whatsapp tersebut aktif tetapi belum dibuka oleh penerima pesan, dan centang dua warna biru berarti pesan terkirim dan sudah dibaca oleh penerima pesan Sehingga kita sebagai pendidik bisa memantau peserta didik yang benarbenar aktif dan tidak.

Dalam pemanfaatan whatsapp sebagai media pembelajaran jarak jauh, pendidik harus memperhatikan beberapa hal, antara lain:

1. Pengenalan terhadap materi pelajaran.

2. Merumuskan tujuan pembelajaran

3. Memberikan pendampingan dan bimbingan kepada peserta didik untuk mempelajari materi.

4. Materi pembelajaran disesuaikan standar yang berlaku secara umum, dan disesuaikan dengan tingkat perkembangan masing-masing peserta didik.

5. Memberikan bantuan dan kemudahan bagi peserta didik untuk mengerajakan tugas-tugas dengan memberikan perintah dan arahan yang jelas.

6. Metode penjelasan yang efektif, jelas dan mudah dipahami oleh peserta didik dengan disertai ilustrasi, contoh, demonstrasi, video dan 
sebagainya.

7. Materi pembelajaran disampaikan dengan sistematis dan mampu memberikan motivasi belajar bagi peserta didik.

8. Materi pembelajaran yang disampaikan disesuaikan dengan kenyataan, sehingga peserta didik mudah untuk memahami, menyerap dan mempraktikannya dalam kehidupan sehari-hari..

Adapun pemanfaatan whatsapp dalam aktivitas edukasi bertujuan;

1. Sebagai sarana edukasi

Guru sebagai tenaga pengajar menjadikan WA sebagai sarana pengontrol sikap siswa. Sikap siswa dapat dibentuk melalui komunikasi multidimensi. Siswa akan menjaga pola tutur katanya dalam berkomunikasi antar sesama anggota. Hal ini akan memunculkan suatu tabiat yang baik, suatu kebiasaan positif hingga menjadi karakter. Sebagai contoh, ketika terlontar pesan yang kotor, guru dapat segera menegur dan memperbaiki. Guru akan terus mengamati alur diskusi para siswanya didalam grup. Saat terdapat perbincangan yang menyimpang dirinya segera terlibat di dalam percakapan, dan jika bersifat pribadi maka nasihat akan disampaikannya melalui japri/menghubungi langsung secara pribadi melalui chat. Sehingga sang siswa tidak merasa dipermalukan di dalam komunitas grup.

Setidaknya terdapat 3 unsur penting yang harus dijaga oleh seorang pendidik agar penggunaan Whatsapp bersifat edukasi. Pertama, pendidik harus berperan sebagai lalu lintas, agar dalam diskusi bisa berjalan dengan tertib dan lancar maka harus ada yang mengatur jalannya diskusi. Misalnya jika ada siswa yang melanggar peraturan tata tertib diskusi maka pendidik harus segera mengurnya dengan cara yang baik. Kedua, pendidik sebagai teman artinya guru memposisikan diri sebagai teman belajar sehingga peserta didik tidak merasa takut untuk menyampaikan pendapatnya. Ketiga, guru sebagai klarifikator, yaitu jika dalam diskusi terdapat peserta didik yang memiliki pemahaman yang keliru maka pendidik harus segera mengklarifikasinya.

2. Sebagai sarana evaluasi 
Whatshapp juga bisa digunakan sebagai sarana untuk melakukan evaluasi bagi peserta didik, meliputi evaluasi kegiatan pembelajaran, evaluasi hasil belajar, dan evaluasi sikap peserta didik selama proses pembelajaran jarak jauh berlangsung.

Aplikasi WhatsApp akan efektif digunakan sebagai sarana evaluasi dalam pendidikan jika melekat padanya tiga unsur. Pertama, guru hendaknya memberi kritikan yang sifatnya membangun, bukan sebaliknya yang justru merendahkan siswa. Kedua, guru secara berkesinambungan memberikan motivasi terhadap hasil kinerja siswa, sekalipun hasilnya belum maksimal. Ketiga, evaluasi sikap bisa dilakukan dengan kisah orang lain untuk di ambil pesan moralnya yang bersifat mendidik.

3. Sebagai sarana penyambung informasi

Whatsaap tidak hanya sekedar sebagai media pembelajaran bagi peserta didik, akan tetapai juga dapat dijadikan sebagai sarana penyambung informasi - informasi kepada siswa itu sendiri ataupun kepada orang tua peserta didik.

Dengan demikian dengan adanya aplikasi whatsaap sangat membantu pihak sekolah dalam memberikan informasi yang sangat cepat, apalagi dalam kondisi pandemic saat ini arus informasi sangatlah cepat berubah, sehingga terkadang pihak sekolah harus dengan cepat menginformasikan kepada peserta didik atau orang tau peserta didik.

4. Sebagai sarana layanan konsultasi dan menjalin silaturahmi

Disamping sebagai media pembelajaran, WA juga bisa dijadikan sarana konsultasi bagi peserta didik dengan pendidik dan sarana menjalin sillaturrohim pendidik denga orang tua peserta didik. Bagi peserta didik misalnya ada anak yang malu bertanya secara langsung mengalami kesulitan/masalah belajar, maka dengan adanaya aplikasi WA ini siswa tersebut bisa melakukan konsultasi kepada pendidik secara bebas terkait masalah yang dihadapinya agar mendapat solusi yang terbaik, atau untuk konsultasi materi pembelajaran yang belum dimengerti oleh siswa.

Sedangkan bagi orang tua peserta didik, dengan adanya WA ini jelas sangat membantu bagi para orang tua dalam memantau 
perkembangan anaknya, apalagi orang tua yang sibuk dengan pekerjaannya tentu disela-sela istirahatnya bisa memanfaatkan aplikasi WA untuk bersilaturrohin dengan pendidik, bisa bercerita tentang permasalahan anaknya dan bediskusi terkait perkembangan anak didiknya tanpa harus datang ke sekolah.

\section{PENUTUP}

Berdasarkan uraian diatas, penulis menyimpulkan bahwa pemanfaatan whatshapp sebagai media pembelajaran ditengan pandemi covid 19 seperti saat ini sangatlah tepat, mengingat aplikasi ini sangat sederhana bila dibandingkan dengan aplikasi online lainnya, mudah dalam pengoperasiannya dan tentunya memiliki fitur-fitur yang banyak. Selain sebagai media pembelajaran pemanfaatan whatsapp dalam aktivitas edukasi bertujuan sebagai sarana edukasi, sebagai sarana evaluasi, sebagai sarana penyambung informasi, dan sebagai sarana layanan konsultasi dan menjalin silaturahim.

Akan tetapi dalam pemanfaatan whatsapp sebagai media pembelajaran jarak jauh, seorang pendidik perlu memperhatikan bebrapa hal, antaralain:

1. Perumusan tujuan pembelajaran yang jelas.

2. Pengenalan materi pelajaran.

3. Adanya kemudahan materi sehingga siswa mudah untuk mempelajarinya.

4. Memberikan tugas-tugas yang mudah disertai dengan perintah dan arahan yang jelas.

5. Materi pembelajaran yang disampaikan disesuaikan dengan standar pada umumnya, dan disesuaikan dengan tingkat perkembangan masing-masing siswa.

6. Materi pembelajaran disampaikan dengan sistematis dan mampu memberikan motivasi belajar.

7. Materi disampaikan sesuai dengan kenyataan, sehingga siswa dengan mudah dapat memahamim menyerap dan mempraktekkannya.

8. Metode yang digunakan harus efektif, jelas dan mudah dipahami oleh siswa, serta perlu disertai dengan contoh, ilustrasi, video, demonstrasi, dan lainnya. 


\section{DAFTAR PUSTAKA}

Aji, Wahyu, Fatma Dewi, Universitas Kristen, and Satya Wacana. "Dampak Covid-19 Terhadap Implementasi Pembelajaran Daring Di Sekolah Dasar." Edukatif: Jurnal Ilmu Pendidikan 2, no. 1 (2020): 55-61. https://edukatif.org/index.php/edukatif/article/view/90.

Hartanto, Wiwin. "Penggunaan E-Learning Sebagai Media Pembelajaran." Jurnal Pendidikan Ekonomi 10, no. 1 (2016): 1-18.

Indaryani, Eka, and Dwi Suliworo. "Dampak Pemanfaatan WhatsApp Dalam Meningkatkan Motivasi Belajar Siswa Pada Pelajaran Fisika." Prosiding Seminar Nasional Quantum 25 (2018): 25-31.

Kusuma, Ade. "E-Learning Dalam Pembelajaran." Lentera Pendidikan 14 (2011): 35-51.

Mudarris, Mudarris. "METODE FORWARD AND BACKWARD STEPS SEBAGAI ALTERNATIF PEMBELAJARAN MATEMATIKA DALAM MENUMBUHKAN MOTIVASI BELAJAR DAN MENINGKATKAN PEMAHAMAN KONSEP BILANGAN BULAT SISWA KELAS VII SMP NURUL AMANAH BANGKALAN." AlInsyiroh: Jurnal Studi Keislaman 2.2 (2018): 115-132.

Pakpahan, Roida, and Yuni Fitriani. "P-ISSN : 2598-8700 ( Printed ) ANALISA PEMANFAATAN TEKNOLOGI INFORMASI DALAM PEMBELAJARAN JARAK JAUH DI TENGAH PANDEMI VIRUS CORONA COVID-19 JISAMAR ( Journal of Information System , Applied , Management, Accounting and Researh ) p-ISSN : 2598-8700 ( Pri." JISAMAR 4, no. 2 (2020): 30-36.

Prasetya, Marzuqi Agung. "E-Learning Sebagai Sebuah Inovasi Metode Active Learning." Edukasia: Jurnal Penelitian Pendidikan Islam 10, no. 2 (2015): 319-338.

Ramdhan, Tri Wahyudin. "Model Pengembangan Kurikulum Multikultural." Al-Insyiroh: Jurnal Studi Keislaman 5.2 (2019): 39-53. Sri Rahayau Candrawati. "Pemanfaatan E-Learning Dalam Pembelajaran." Jurnal Cakrawala Kependidikan Cakrawala Kependidikan (n.d.): 172181.

Suryani, Rani. "Fungsi Whatsapp Grup Shalihah Cabang Bandar Lampung Sebagai Pengembangan Media Dakwah Dalam Membentuk Akhlakul 
Karimah" (2017).

Trisnani, -. "Pemanfaatan Whatsapp Sebagai Media Komunikasi Dan Kepuasan Dalam Penyampaian Pesan Dikalangan Tokoh Masyarakat." Jurnal Komunika : Jurnal Komunikasi, Media dan Informatika 6, no. 3 (2017).

Yuliana. "Corona Virus Diseases (Covid -19); Sebuah Tinjauan Literatur."

Wellness and healthy magazine 2, no. 1 (2020): 187-192. https://wellness.journalpress.id/wellness/article/view/v1i218wh.

Yusmita, Mei, Zulfiah Larisu, and Saidin. "Pemanfaatan WhatsApp Messenger Sebagai Media Komunikasi Antar Pribadi Mahasiswa Ilmu Komunikasi *Mei Yusmita ** Dr. Zulfiah Larisu, S.Sos, M.Si., *** Saidin, S.Ip, M.Si.” (2014): 1-12.

Zainiati, Husniyatus Salamah. "Understanding the Cognition Process of the Students Using the Internet as a Learning Resource.” Jurnal Pendidikan Islam 3, no. 1 (2017): 57.

“Penggunaan Media Belajar Whatsaapp.” Skripsi 53, no. 9 (2019): 16891699. 